Research Article

\title{
Micropropagation of Livingstone Potato (Plectranthus esculentus N.E.Br)
}

\author{
G. T. Kujeke $\mathbb{D}$, T. C. Chitendera, R. T. Masekesa, U. Mazarura, E. Ngadze, J. T. Rugare $\mathbb{D}$, \\ and A. Matikiti
}

University of Zimbabwe, Faculty of Agriculture, Department of Crop Science, Mount Pleasant, Harare, Zimbabwe

Correspondence should be addressed to G. T. Kujeke; gtmkujeke@gmail.com

Received 17 June 2019; Revised 20 November 2019; Accepted 4 December 2019; Published 6 June 2020

Academic Editor: Othmane Merah

Copyright $\odot 2020$ G. T. Kujeke et al. This is an open access article distributed under the Creative Commons Attribution License, which permits unrestricted use, distribution, and reproduction in any medium, provided the original work is properly cited.

\begin{abstract}
Livingstone potato (Plectranthus esculentus N.E.Br) is an underutilised indigenous root vegetable grown by communal farmers in the eastern provinces of Zimbabwe. It is vegetatively propagated using unimproved retained tubers from the previous season. The risk of disease carryover is therefore high, leading to poor yields. The objective of the study was to exploit the tissue culture technique of micropropagation to produce a mass supply of healthy planting material for improved productivity. Two experiments were conducted: firstly, to determine the best explant type and secondly, to determine the best landrace and plant growth regulators for the growth of plantlets. The landraces, namely, Ndurwe, Musande, Chibanda, and Chizambezi, were sourced from communal farmers in the stated production areas. Naphthalene acetic acid (NAA) and benzyl amino purine (BAP) were the auxin and cytokinin used, respectively. The first experiment was laid out as a randomized complete block design (RCBD) with two factors: landrace and explant type (shoot tips, nodes, and leaves). After culturing the explants on a plain Murashige Skoog (MS) medium for ten weeks, the best explant was the node with regards to the number of nodes, shoots, and roots of the plantlets which were significant $(P<0.05)$. The second experiment was laid out as a RCBD with two factors: landraces and the plant growth regulator combinations. The nodes were subcultured on an MS medium supplemented with the 16 combinations of plant growth regulators $(0 \mathrm{mg} / \mathrm{l}, 0.5 \mathrm{mg} / \mathrm{l}, 1 \mathrm{mg} / \mathrm{l}$, and $2 \mathrm{mg} / \mathrm{l}$ BAP concentrations: $0 \mathrm{mg} / \mathrm{l}, 0.2 \mathrm{mg} / \mathrm{l}, 0.5 \mathrm{mg} / \mathrm{l}$, and $1 \mathrm{mg} / \mathrm{l} \mathrm{NAA}$ concentrations), respectively. Chizambezi performed best and is, therefore, highly recommended for the rapid multiplication of Livingstone potato. Results from this study have clearly demonstrated that the addition of NAA: BAP at varying concentrations was significant and is essential for optimizing the growth media for micropropagation of Livingstone potato in Zimbabwe. Commercial production of plantlets can, therefore, be carried out to provide healthy planting material for the communal farmers for improved productivity while preserving the germplasm of the underutilised crop at the same time.
\end{abstract}

\section{Introduction}

Livingstone potato or wild potato (Plectranthus esculentus N.E.Br) is a perennial herbaceous plant, which belongs to the Lamiaceae family and is grown for its edible tubers. The crop can be propagated sexually using seed, but the development of the crop is slow and the offspring is heterogeneous [1]. Communal farmers in Zimbabwe produce the crop asexually using small tubers which are retained from last season's crop $[2,3]$. Although this ensures the maintenance of lines, the risk of disease carryover into the next season is very high and eventually leads to a decline in potential yield. Another disadvantage of using this method is the low multiplication rate of the planting material [4]. For root vegetable crops like Livingstone potato, the availability of adequate disease-free planting material is a constraint to increased productivity, and as such, the crop remains neglected and underutilised in Zimbabwe [2].

Underutilised crops such as Livingstone potato are characterized by low yields [1-3]. However, they still remain relevant as they will produce harvestable yields where major food crops may fail [5]. Tindall [6] stated that the yield of Livingstone potato can be as low as two to six tonnes per hectare, while Schippers [1] highlighted yield potentials of 
up to $60 \mathrm{t} /$ ha under optimal experimental conditions using tissue culture produced plantlets in South Africa [7].

Biotechnology has been used effectively as a tool for the improvement of several vegetatively propagated crops. Tissue culture techniques are deemed as the easiest to implement initially, and micropropagation is a valuable and much used technique for the multiplication of many vegetatively propagated food crops like sweet potato, yam (Dioscorea spp), potato (Solanum tuberosum), and banana and plantain (Musa spp) [8]. Advances in tissue culture techniques have facilitated the production, multiplication, and maintenance of disease-free plants for these crops [9]. The rapid multiplication of plant tissues, however, requires the optimization of plant growth regulator (PGR) concentrations in the Murashige and Skoog media. The PGR requirements tend to vary with species since they determine the course of morphogenesis [10].

Research into the micropropagation of the Plectranthus species has been conducted [11-14]; however, there has been no reported research conducted on the micropropagation of the Livingstone potato landraces indigenous to Zimbabwe. The option of using the rapidly produced disease-free planting material is, therefore, currently not available for the producers. The high yields (60t/ha) obtained under experimental conditions in South Africa [7] clearly demonstrate a need for optimizing the current traditional production methods in Zimbabwe with regards to the planting material. The objective of this study was to explore the micropropagation of Livingstone potato landraces found in Zimbabwe as a step in providing communal farmers with healthy planting material, thus improving productivity for the underutilised crop. Existing micropropagation protocols for the Livingstone potato were employed in this study to enable optimization for the indigenous landraces found in Zimbabwe.

\section{Materials and Methods}

2.1. Source of Livingstone Potato Landraces and Preparation. Four Livingstone potato landraces, namely, HRCTzD0001 (Ndurwe), HRCTzS0011 (Chizambezi), HRCTzD0003 (Chibanda), and HRCTzD0007 (Musande) were harvested from farmers in the in the Marondera district of the Mashonaland East province of Zimbabwe. Marondera district lies in Natural Region IIb of the agro ecological zones of Zimbabwe. The region is characterized by an annual average rainfall of $850 \mathrm{~mm}$ and severe dry spells during the rainy season. Soils are greyish brown sands and sandy loams derived from granitic rocks [15]. The farmers produce the crop on ridges in wetlands and with no application of fertilizers. The tubers are ready for harvest after six to nine months [1-3].

For each landrace, the tubers were obtained from one single plant weighing approximately $1.3 \mathrm{~kg}$ [13]. The freshly harvested tubers were then taken to the University of Zimbabwe in Harare, where they were kept at room temperature for a period of four weeks in the laboratory to enable the healing of minor cuts and bruises and thicken the skin of the tubers. The tubers were then washed in a detergent solution (one part sunlight liquid detergent to nine parts water) and thoroughly rinsed in distilled water. Small slits were cut on the tubers which were then soaked in a 5\% gibberellic acid solution ( $5 \mathrm{ml} \cdot \mathrm{GB} /$ litre of distilled water) for 10 minutes to encourage sprouting. The cuts were made to enable the rapid absorption of the GA [4]. The tubers were then air dried and left on trays in dark cupboards until sprouting occurred. Different parts of the sprouts (which were left to grow to a length of $5 \mathrm{~cm}$ ) were then used as the sources of the explants. Two experiments were conducted in the laboratory at the University of Zimbabwe Crop Science Department, which has an average temperature of $25^{\circ} \mathrm{C}$ and a relative humidity between $50-70 \%$.

\subsection{Experiment 1: Effect of Explant Type on Root and Shoot Development of Livingstone Potato}

2.2.1. Culture Medium Preparation. The aim of the experiment was to determine a suitable explant type (shoot tips, nodes, and leaves) for the micropropagation of Livingstone potato. A standard culture medium containing the full strength of macronutrients and micronutrients, as well as vitamins as described by Murashige and Skoog [16], was used in the study. The Murashige and Skoog (MS) medium was supplemented with $30 \mathrm{~g}$ of sucrose and vitamins, and the $\mathrm{pH}$ was adjusted to $5.6-5.8$ using $0.5 \mathrm{M}$ sodium hydroxide. Three grams per litre of Gelrite ${ }^{\mathrm{TM}}$ was added as the solidifying agent, and the sterilized culture vessels were filled $20 \mathrm{ml}$ each with the MS medium. These were then autoclaved for 15 minutes at $121^{\circ} \mathrm{C}$ and $15 \mathrm{kPa}$ and left to cool down and solidify at room temperature.

2.2.2. Surface Sterilization of Explants. The explants (shoots tips, nodes, and leaves) cut from the sprouted tubers were washed in a weak soapy water solution to remove any plant debris adhering to the explants. The explants were placed in a beaker with two drops of Tween-20 and agitated to reduce surface tension and then left under running water overnight to create an isotonic solution inside the segments. After the washing procedure, the explants were then soaked in $10 \%$ concentration of sodium hypochloride for 15 minutes and then rinsed three times in sterile distilled water to remove the disinfectant. This procedure was performed under aseptic conditions in a laminar airflow hood. The basal end tips of the explants were trimmed to remove bleach damaged tissue. A 70\% ethanol solution was prepared and used for the surface sterilization of the apparatus and the laminar airflow cabinet [17].

2.2.3. Capturing of the Explants. The explants (leaves, nodes, and shoot tips) which were approximately $10 \mathrm{~mm}$ were excised using a sterile scalpel on a white tile and placed in sterile culture vessels with solidified MS medium using a pair of sterilized forceps. The culture vessel caps were sealed with Parafilm $^{\mathrm{TM}}$ [13]. The cultures were placed in the growth room on top of polystyrene sheets where the temperature was kept at $27 \pm 2^{\circ} \mathrm{C}$, and a 16 hour light: 8 hour dark photoperiod was 
maintained [18]. The cultures were checked for contamination three days after capturing for bacterial infections and six days after capturing for fungal infections. All infected materials were then discarded.

2.2.4. Experimental Procedure and Data Analysis. The experimental design was a $4 \times 3$ factorial laid out in a randomized complete block design (RCBD). The experiment had two factors, three blocks, and twelve treatments replicated three times in each block. The first factor was the landrace at four levels (Ndurwe, Musande, Chibanda, and Chizambezi), and the second factor was the explant type at three levels (shoot tips, nodes, and leaves). The treatments were blocked against light and distance from the door. The cultures were observed on a daily basis, and the number of days to root and shoot initiation was monitored and recorded. After ten weeks of culturing, the shoot length was measured using a ruler, and shoot number, leaf number, and number of nodes on the shoot were physically counted and recorded. The data collected were then subjected to analysis of variance (ANOVA) using the Genstat Statistical package version 18. Means were separated using 5\% Fisher's least significant difference (LSD) test. The best explant (nodes) according to the results was then used in the second experiment.

\subsection{Experiment 2: Effect of Landrace and Plant Growth Regulators on the Growth of Livingstone Potato Plantlets}

2.3.1. Experimental Procedure. To optimize the medium for the development and growth of Livingstone potato plantlets from nodes, different combinations of auxin: cytokinin were tested. The auxin used was naphthalene acetic acid (NAA), while benzyl amino purine (BAP) was the cytokinin used. Different combinations of NAA and BAP growth regulators were added to the MS medium to make up the respective 64 treatments, as shown in Table 1 . The $0 \mathrm{mg} / \mathrm{l}$ of NAA: BAP was used as the control and contained the MS medium only. The experimental design was a $4 \times 16$ factorial laid out in a RCBD with two factors and three blocks with three replications. The first factor was the landraces at four levels (Ndurwe, Musande, Chibanda, and Chizambezi), and the second factor was the NAA: BAP combinations (NAA at $0 \mathrm{mg} / \mathrm{l}, 0.2 \mathrm{mg} / \mathrm{l}, 0.5 \mathrm{mg} / \mathrm{l}$, and $1 \mathrm{mg} / \mathrm{l}$ concentrations: BAP at $0 \mathrm{mg} / \mathrm{l}, 0.5 \mathrm{mg} / \mathrm{l}, 1 \mathrm{mg} / \mathrm{l}$, and $2 \mathrm{mg} / \mathrm{l}$ concentrations) at sixteen levels (Table 1).

2.3.2. Medium Preparation and Subculturing. Standard stock solutions $(1 \mathrm{mg} / \mathrm{ml})$ of the growth regulators BAP and NAA were prepared by dissolving $50 \mathrm{mg}$ of each of the growth regulators in two separate beakers with a few drops of ethanol and then adding distilled water to bring the volume to $50 \mathrm{ml}$. The MS medium was prepared as described in Section 2.2.1 and poured into 16 separate beakers where the different plant growth regulator combinations (BAP: NAA), shown in Table 1, were then added. The $\mathrm{pH}$, sucrose, and Gelrite ${ }^{\mathrm{TM}}$ were adjusted and added, respectively, as
TABLE 1: NAA: BAP combinations.

\begin{tabular}{lcccc}
\hline \multirow{2}{*}{ NAA $(\mathrm{mg} / \mathrm{l})$} & \multicolumn{4}{c}{ BAP $(\mathrm{mg} / \mathrm{l})$} \\
& 0 & 0.5 & 1 & 2 \\
\hline 0 & $\mathrm{~A}(0: 0)$ & $\mathrm{B}(0: 0.5)$ & $\mathrm{C}(0: 1)$ & $\mathrm{D}(0: 2)$ \\
0.2 & $\mathrm{E}(0.2: 0)$ & $\mathrm{F}(0.2: 0.5)$ & $\mathrm{G}(0.2: 1)$ & $\mathrm{H}(0.2: 2)$ \\
0.5 & $\mathrm{I}(0.5: 0)$ & $\mathrm{J}(0.5: 0.5)$ & $\mathrm{K}(0.5: 1)$ & $\mathrm{L}(0.5: 2)$ \\
1 & $\mathrm{M}(1: 0)$ & $\mathrm{N}(1: 0.5)$ & $\mathrm{O}(1: 1)$ & $\mathrm{P}(1: 2)$ \\
\hline
\end{tabular}

described in Section 2.2.1 including the pouring of the prepared media into the culture vessels. Ten millimetre-long nodes which were the best explant from the first experiment were obtained from the four landraces. These were cut using a sterile blade and then subcultured onto the solid MS medium with different concentrations of the NAA and BAP using sterile forceps into the culture vessels. This process was performed under aseptic conditions in a laminar airflow cabinet. After capturing, the cultures were incubated in a growth room, and the environmental conditions were maintained as described in Section 2.3.3 including the contamination checks.

2.3.3. Data Collection and Analysis. Data collection was as described in Section 2.2.4. Ndurwe explants cultured using the NAA: BAP combinations J $(0.5: 0.5), \mathrm{L}(0.5: 2)$, and P $(1$ : 2) did not show any signs of growth during the 10 week period of the study; therefore, they were removed from the analysis. The data were, therefore, treated as an unbalanced ANOVA using GenStat Statistical package version 18. Graphs were constructed using R statistical package. Means were separated using 5\% Fisher's least significant difference (LSD) test.

\section{Results}

\subsection{Experiment 1: Effect of Explant Type Shoot Development of Livingstone Potato}

3.1.1. Effect of Landrace and Explant Type on the Average Shoot Number. The landrace, explant type, and the landrace $x$ explant type interaction effects were significant $(P<0.05)$ on the mean shoot number. The interaction resulted in Musande nodes producing the highest mean shoot number which was not significantly different $(P>0.05)$ from that of the Musande shoot tip. The Ndurwe leaf explant produced the least number of shoots which performed statistically the same with the leaf and shoot tips from the other landraces as well as the nodes from Chibanda and Chizambezi (Table 2).

3.1.2. Effect of Landrace and Explant on the Average Number of Nodes per Shoot. The effect of the explant type was not significant $(P>0.05)$, while the landrace and the landrace $x$ explant type effects were significant $(P<0.05)$ on the average number of nodes per shoot. Musande nodes produced shoots with the highest number of nodes which was statistically similar to that of the Ndurwe shoot tip. The Ndurwe leaf explant produced the least number of nodes per shoot, and this was not significantly different to the leaf and shoot 
TABLE 2: Effect of landrace and explant on the average shoot number.

\begin{tabular}{lcll}
\hline Treatment & Shoot number & \\
\hline Ndurwe leaf & $0.56^{\mathrm{a}}$ & & \\
Chibanda leaf & $0.67^{\mathrm{a}}$ & & \\
Musande leaf & $0.78^{\mathrm{a}}$ & & \\
Ndurwe shoot tip & $0.89^{\mathrm{ab}}$ & & \\
Chibanda shoot tip & $0.89^{\mathrm{ab}}$ & & \\
Chizambezi node & $0.89^{\mathrm{ab}}$ & & \\
Chizambezi leaf & $0.89^{\mathrm{ab}}$ & & \\
Chibanda node & $1.00^{\mathrm{abc}}$ & & \\
Chizambezi shoot tip & $1.22^{\mathrm{abc}}$ & & \\
Ndurwe node & $1.56^{\mathrm{bc}}$ & & \\
Musande shoot tip & $1.67^{\mathrm{cd}}$ & & \\
Musande node & $2.33^{\mathrm{d}}$ & & \\
\hline & $P$ value & SED & $\mathrm{LSD}_{0.05}$ \\
Landrace & 0.002 & 0.198 & 0.395 \\
Explant & $<0.001$ & 0.172 & 0.342 \\
Explant $x$ landrace interaction & 0.044 & 0.345 & 0.684 \\
\hline
\end{tabular}

Means followed by the same letters in a column are not significantly different at LSD (0.05)

tips of other landraces as well as nodes from Ndurwe and Chizambezi (Table 3).

\subsection{Experiment 2: Effect of the Plant Growth Regulators on the Growth of Livingstone Potato Plantlets}

3.2.1. Effect of Landraces and NAA: BAP Combination on Days to Root Initiation. A significant landrace $x$ NAA: BAP interaction $(P<0.001)$ on days to root initiation was observed. Chibanda and Chizambezi each initiated roots in the shortest time when cultured using the NAA: BAP combination K $(0.5: 1)$, while Musande took the longest time for root initiation when no plant growth regulators were added (NAA: BAP combination A $(0: 0)$ ), as shown in Figure 1. Ndurwe showed no root initiation during the 10 week time frame for the NAA: BAP combinations of $J(0.5$ : $0.5), \mathrm{L}(0.5: 2)$ and $\mathrm{P}(1: 2)$.

3.2.2. Interaction of Landraces and the NAA: BAP Combination on Days to Shoot Initiation. The landrace, NAA: BAP combination, and the landrace $x$ NAA: BAP interaction effects were significant $(P<0.05)$ on the time taken to shoot initiation. The interaction resulted in the landraces responding differently to the NAA: BAP combinations, as presented in Figure 2. Chibanda and Chizambezi both had the least number of days to shoot initiation as the concentration of the plant growth regulators increased. Chizambezi also had the same result at the highest NAA: BAP combinations although the time taken was not significantly different $(P>0.05)$ from the NAA: BAP combinations $\mathrm{D}, \mathrm{H}$, and L. Musande took the longest time to initiate shoots when cultured using the NAA: BAP combination of E $(0.2: 0)$ (Figure 2). Ndurwe showed no shoot initiation during the time frame of 10 weeks for the same NAA: BAP combinations of $\mathrm{J}(0.5: 0.5)$, L $(0.5: 2)$, and $\mathrm{P}(1: 2)$.
3.2.3. Effect of Landraces and the NAA: BAP Combination on the Shoot Number. The landrace and NAA: BAP combination effects were significant $(P<0.05)$ on the shoot number. A significant interaction $(P<0.001)$ was observed between the landrace and NAA: BAP combination on the mean shoot number. Musande and Ndurwe produced the highest mean shoot numbers which were the same statistically when both landraces were cultured using the NAA: BAP $(0.2: 1)$ combination. However, the shoots were noticeably small structurally and short $(0.7 \mathrm{~cm}-0.5 \mathrm{~cm}$, respectively). Ndurwe did not produce any shoots when the explants were cultured using the A $(0: 0), \mathrm{C}(0: 1), \mathrm{J}(0.5$ : $0.5)$, and L $(0.5: 2)$ NAA: BAP combinations (Figure 3$)$.

\subsubsection{Effect of Landraces and the NAA: BAP Combination on} the Leaf Number. There was a significant $(P<0.001)$ landrace $x$ NAA: BAP interaction on the leaf number. Ndurwe produced the highest mean leaf number at NAA: BAP combination $M(1: 0)$ which was not significantly different $(P>0.05)$ from that of Chizambezi at the same concentration. A noticeable trend was that as the concentration of the plant growth regulators was increased, Chizambezi produced high leaf numbers which were not significantly different $(P>0.05)$ amongst 5 different NAA: BAP combinations (C, E, I, J and M) (Figure 4). Ndurwe and Chibanda were also not significantly different with the gradual increase for three NAA: BAP combinations each (B, C, D, E, L, and M). Treatments J, L, and P had no leaf number readings as there was no growth for Ndurwe (Figure 4).

There was a significant $(P<0.001)$ landrace $x$ NAA: BAP interaction on the node number with Chizambezi having the highest mean node number at the NAA: BAP combination of I which was not significantly different at $M$ for the same landrace. This result was statistically the same for Chibanda cultured at NAA: BAP combinations A, C, D, and I, for Ndurwe at $\mathrm{E}$ and $\mathrm{M}$ and for Musande at NAA: BAP combination $\mathrm{O}$. On the other hand, Ndurwe at $\mathrm{C}$ had no nodes (Figure 5).

3.2.5. Effect of Landraces and the NAA: BAP Combination on the Shoot Length. The landrace $x$ NAA: BAP interaction effects on shoot length were significant $(P<0.05)$. Musande produced plantlets with the longest shoots at NAA: BAP combination $\mathrm{F}(0.2: 0.5)$ which was not significantly different from that of Musande at $\mathrm{O}(1: 1)$, as well as Ndurwe at $\mathrm{D}(0: 2), \mathrm{E}(0.2: 0)$, and $\mathrm{M}(1: 0)$. No shoot lengths were recorded for Ndurwe at NAA: BAP combinations J, L, and $\mathrm{P}$ due to the absence of growth (Figure 6).

3.2.6. Summary of Landrace Performance due to Application of Plant Growth Regulators. A summary of the effects of landraces cultured in MS with different PGRs combinations cultured over a period 10 weeks is shown in Table 4. For each parameter, the best performing landraces and the corresponding NAA: BAP combinations are stated. The NAA: BAP concentrations are stated from the lowest concentration to the highest for the best performing landrace. For all 
TABLE 3: Effect of landrace and explant on the average number of nodes per shoot.

\begin{tabular}{|c|c|c|c|}
\hline Treatment & Number of nodes per shoot & & \\
\hline Ndurwe leaf & $1.67^{\mathrm{a}}$ & & \\
\hline Chizambezi shoot tip & $1.78^{\mathrm{a}}$ & & \\
\hline Chibanda leaf & $2.22^{\mathrm{ab}}$ & & \\
\hline Chibanda shoot tip & $2.56^{\mathrm{abc}}$ & & \\
\hline Ndurwe node & $2.67^{\mathrm{abc}}$ & & \\
\hline Chizambezi node & $3.11^{\mathrm{abcd}}$ & & \\
\hline Chizambezi leaf & $3.11^{\mathrm{abcd}}$ & & \\
\hline Musande leaf & $3.67^{\mathrm{bcd}}$ & & \\
\hline Musande shoot tip & $4.00^{\mathrm{cd}}$ & & \\
\hline Chibanda node & $4.11^{\mathrm{cd}}$ & & \\
\hline Ndurwe shoot tip & $4.11^{\mathrm{cd}}$ & & \\
\hline Musande node & $4.56^{\mathrm{d}}$ & & \\
\hline & $P$ value & SED & $\mathrm{LSD}_{0.05}$ \\
\hline Landrace & 0.024 & 0.5 & 0.993 \\
\hline Explant & 0.098 & 0.43 & NS \\
\hline Explant $x$ landrace interaction & 0.054 & 0.87 & 1.72 \\
\hline
\end{tabular}

Means followed by the same letters in a column are not significantly different at LSD (0.05).

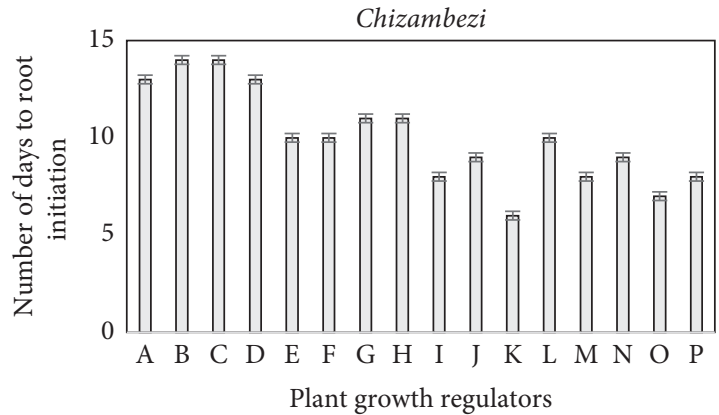

(a)

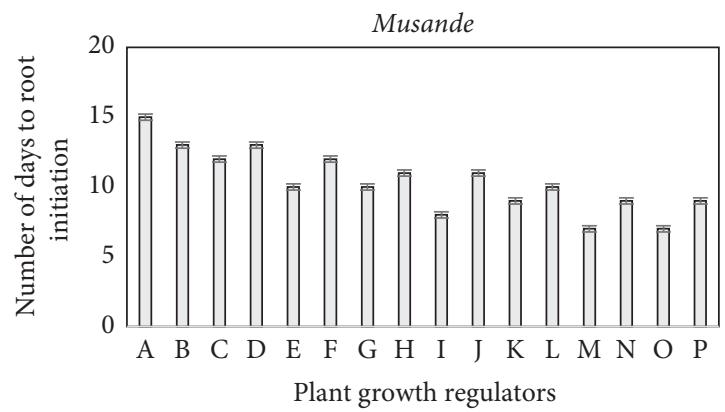

(c)

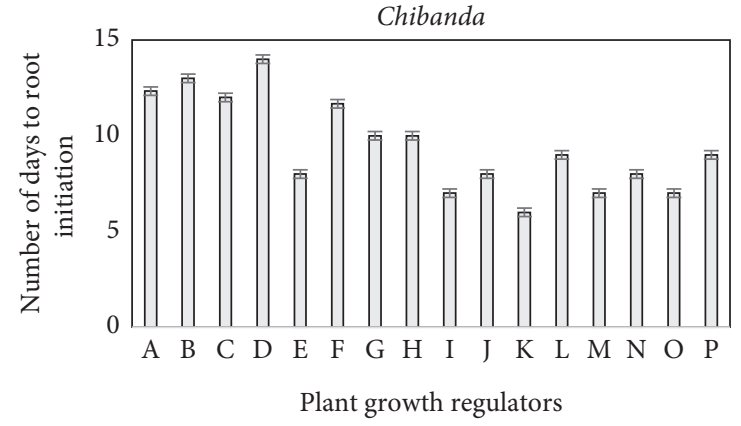

(b)

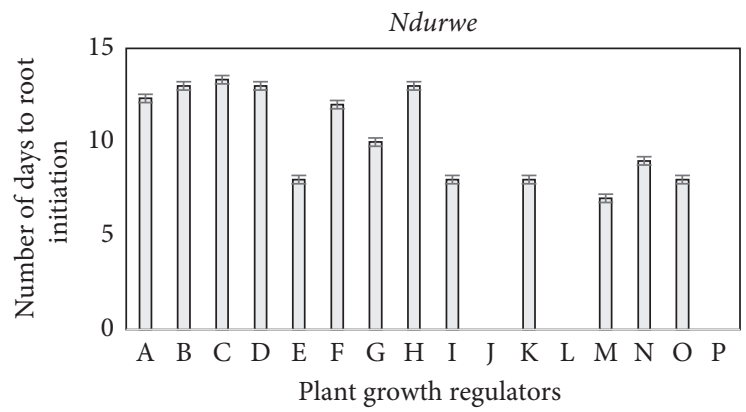

(d)

FIgURE 1: Mean days to root initiation of the Livingstone potato landraces in response to NAA: BAP in $\mathrm{mg} / \mathrm{l}$ application. $P<0.001, \mathrm{LSD}=3.22$. Error bars represent standard errors of the differences. Plant growth regulators key: A $(0 \mathrm{mg} / \mathrm{l}: 0 \mathrm{mg} / \mathrm{l}), \mathrm{B}(0 \mathrm{mg} / \mathrm{l}: 0.5 \mathrm{mg} / \mathrm{l}), \mathrm{C}(0 \mathrm{mg} / \mathrm{l}: 1 \mathrm{mg} / \mathrm{l})$, $\mathrm{D}(0 \mathrm{mg} / \mathrm{l}: 2 \mathrm{mg} / \mathrm{l}), \mathrm{E}(0.2 \mathrm{mg} / \mathrm{l}: 0 \mathrm{mg} / \mathrm{l}), \mathrm{F}(0.2 \mathrm{mg} / \mathrm{l}: 0.5 \mathrm{mg} / \mathrm{l}), \mathrm{H}(0.2 \mathrm{mg} / \mathrm{l}: 2 \mathrm{mg} / \mathrm{l}), \mathrm{I}(0.5 \mathrm{mg} / \mathrm{l}: 0 \mathrm{mg} / \mathrm{l}), \mathrm{J}(0.5 \mathrm{mg} / \mathrm{l}: 0.5 \mathrm{mg} / \mathrm{l}), \mathrm{J}(0.5 \mathrm{mg} / \mathrm{l}:$ $0.5 \mathrm{mg} / \mathrm{l}), \mathrm{K}(0.5 \mathrm{mg} / \mathrm{l}: 1 \mathrm{mg} / \mathrm{l}), \mathrm{L}(0.5 \mathrm{mg} / \mathrm{l}: 2 \mathrm{mg} / \mathrm{l}), \mathrm{M}(1 \mathrm{mg} / \mathrm{l}: 0 \mathrm{mg} / \mathrm{l}), \mathrm{N}(1 \mathrm{mg} / \mathrm{l}: 0.5 \mathrm{mg} / \mathrm{l}), \mathrm{O}(1 \mathrm{mg} / \mathrm{l}: 1 \mathrm{mg} / \mathrm{l})$, and $\mathrm{P}(1 \mathrm{mg} / \mathrm{l}: 2 \mathrm{mg} / \mathrm{l})$.

the growth parameters measured, the addition of PGRSs gave positive results, and the only exception was the Chibanda landrace which had a high response on node numbers when no PGRSs were used (Table 4). While all the landraces managed to produce plantlets, Chizambezi was evaluated as the best landrace for micropropagation with good results most of the parameters measured using a range of $0-1 \mathrm{mg} / \mathrm{l}$ of NAA: $0.5-2 \mathrm{mg} / \mathrm{l}$ of BAP combinations (Table 4).

\section{Discussion}

Micropropagation is regarded as a fast method of multiplying plants and has great potential to develop high-quality and disease-free plants. Advancements in this field have led to the development of several techniques for the rapid multiplication and improvement of a wide range of horticultural crops and their production systems [19]. Amongst 


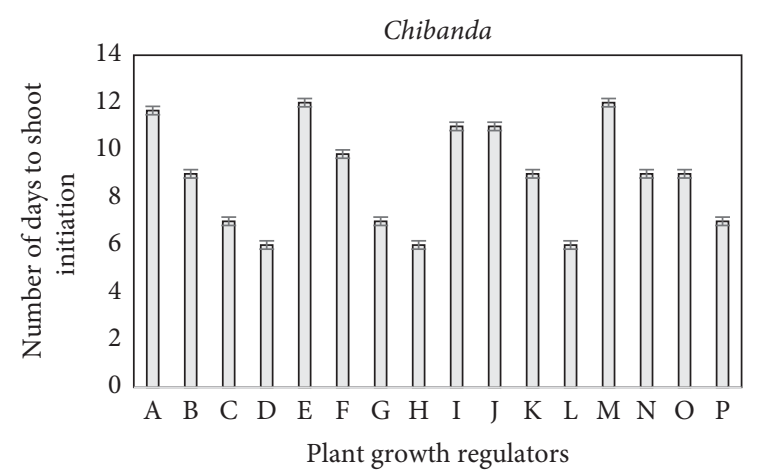

(a)

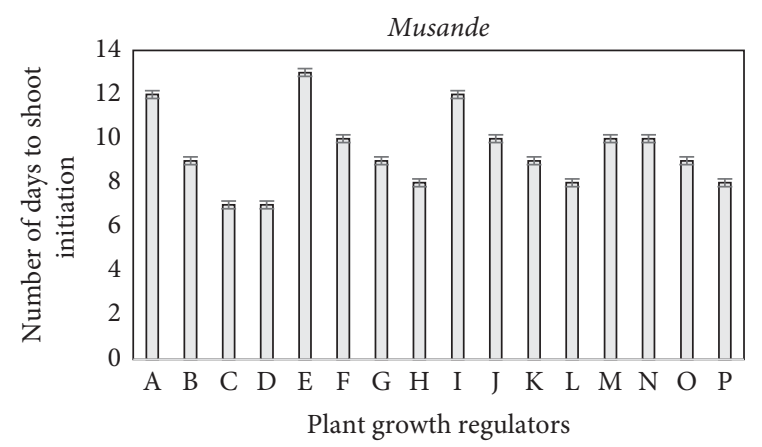

(c)

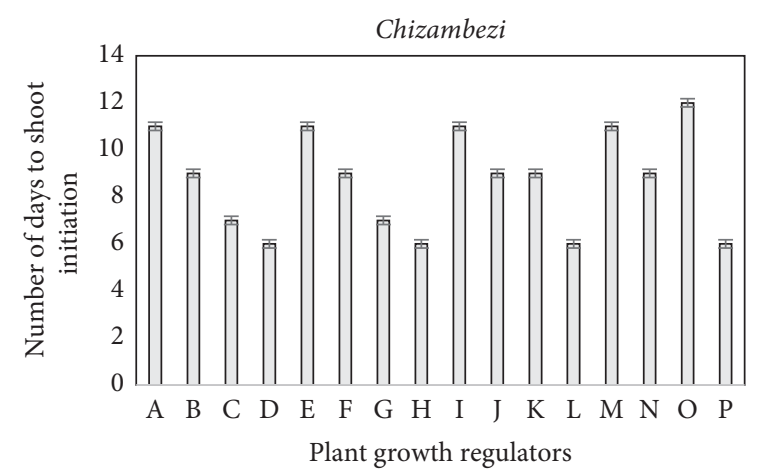

(b)

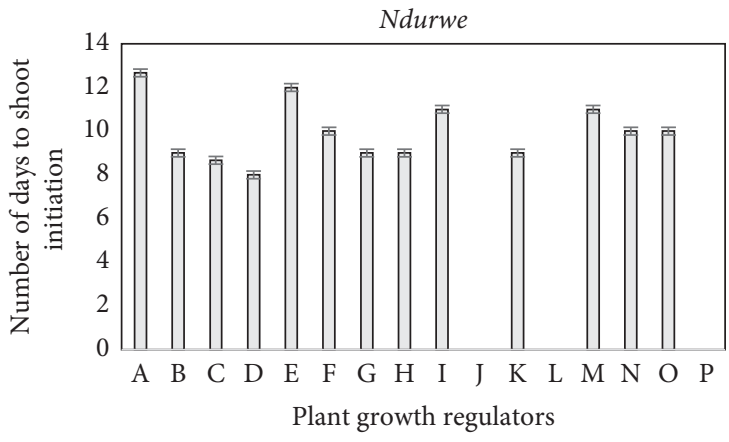

(d)

Figure 2: Mean days to shoot initiation of the Livingstone potato landraces in response to NAA: BAP in mg/l application. $P<0.001$, $\mathrm{LSD}=2.82$. Error bars represent standard errors of the differences. Plant growth regulators key: A $(0 \mathrm{mg} / \mathrm{l}: 0 \mathrm{mg} / \mathrm{l}), \mathrm{B}(0 \mathrm{mg} / \mathrm{l}: 0.5 \mathrm{mg} / \mathrm{l}), \mathrm{C}$ $(0 \mathrm{mg} / \mathrm{l}: 1 \mathrm{mg} / \mathrm{l}), \mathrm{D}(0 \mathrm{mg} / \mathrm{l}: 2 \mathrm{mg} / \mathrm{l}), \mathrm{E}(0.2 \mathrm{mg} / \mathrm{l}: 0 \mathrm{mg} / \mathrm{l}), \mathrm{F}(0.2 \mathrm{mg} / \mathrm{l}: 0.5 \mathrm{mg} / \mathrm{l}), \mathrm{H}(0.2 \mathrm{mg} / \mathrm{l}: 2 \mathrm{mg} / \mathrm{l}), \mathrm{I}(0.5 \mathrm{mg} / \mathrm{l}: 0 \mathrm{mg} / \mathrm{l}), \mathrm{J}(0.5 \mathrm{mg} / \mathrm{l}:$ $0.5 \mathrm{mg} / \mathrm{l}), \mathrm{J}(0.5 \mathrm{mg} / \mathrm{l}: 0.5 \mathrm{mg} / \mathrm{l}), \mathrm{K}(0.5 \mathrm{mg} / \mathrm{l}: 1 \mathrm{mg} / \mathrm{l}), \mathrm{L}(0.5 \mathrm{mg} / \mathrm{l}: 2 \mathrm{mg} / \mathrm{l}), \mathrm{M}(1 \mathrm{mg} / \mathrm{l}: 0 \mathrm{mg} / \mathrm{l}), \mathrm{N}(1 \mathrm{mg} / \mathrm{l}: 0.5 \mathrm{mg} / \mathrm{l}), \mathrm{O}(1 \mathrm{mg} / \mathrm{l}: 1 \mathrm{mg} / \mathrm{l}), \mathrm{and}$ $\mathrm{P}(1 \mathrm{mg} / \mathrm{l}: 2 \mathrm{mg} / \mathrm{l})$.

these horticultural crops are underutilised and neglected vegetables such as sweet potato and taro (Colocasia esculenta) [20] whose micropropagation and germplasm preservation have been successful [21-25]. In this study, the Livingstone potato was also subjected to micropropagation techniques, and the results are discussed here.

While the micropropagation of the Livingstone potato has been previously carried out $[13,26]$, genetic differences within the Plectranthus species call for the optimization of the regeneration protocol. The plant material used in this study was from Livingstone potato landraces Chibanda, Ndurwe, Chizambezi, and Musande which are indigenous to Zimbabwe. The explant source has been proved to be an important factor for in vitro growth and development of plant species, affecting callus induction and adventitious bud induction as well as shoot regeneration [27]. Physiologically, younger plant tissue is generally regarded to be more responsive in vitro [28] and this was taken into account in this study by using the sprouts of the tuberous roots. The different explants were cultured in the MS medium which is the most widely used culture medium that most plant cell cultures react to favourably [29].

Kyesmu [11] developed the original basic protocol for the micropropagation of Livingstone potato and used shoots and nodes as the explants. In previous research carried out by Allemann [13], Livingstone potato sprouts were used as the source of explant material where axillary buds and shoots were cultured and successfully produced plantlets. In this study, shoot tips, nodes, and leaves were used to determine the best explant on the four landraces. Plant regeneration was successfully achieved by all the explant types. This can be explained by the aspect of totipotency, a cell characteristic which plant tissues have that aids them to retain regeneration potential from the adult organism. Organogenesis allowed roots and shoots to be induced and differentiate in the respective explants that were used in the study [29]. However, the least shoots, nodes, and roots were recorded when leaf explants were used because leaves have fewer axillary buds that can develop into shoots. In addition, the levels of endogenous growth regulators in leaves which would promote root and shoot development are also low. The results of this study are in agreement with those that were obtained by Addae-Frimpomaah et al. [18] and Doliński and Olek [22] on in vitro propagation of sweet potato node explants.

The genetic differences within the species are demonstrated in the different responses exhibited by the four landraces of Livingstone potato using the different types of explants. The results are in agreement with Ogero [30], who showed that differences existed between two sweet potato varieties with regards to their response to micropropagation. The best explant across the landraces was the node, thus 


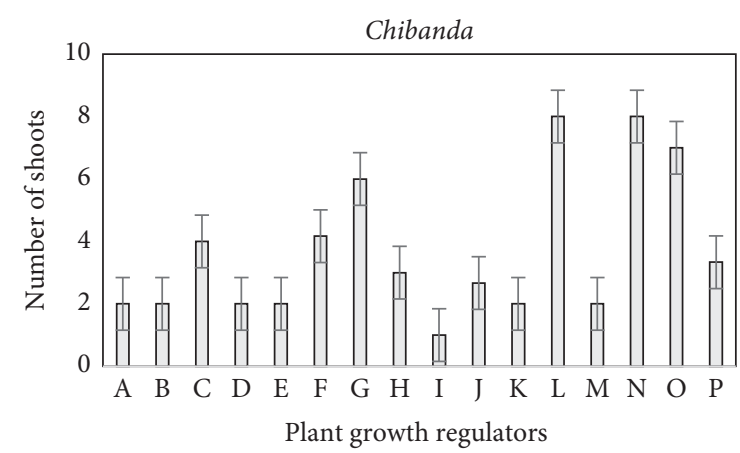

(a)

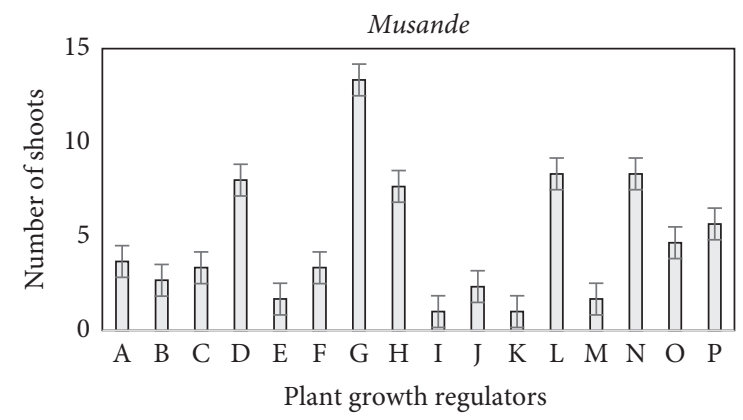

(c)

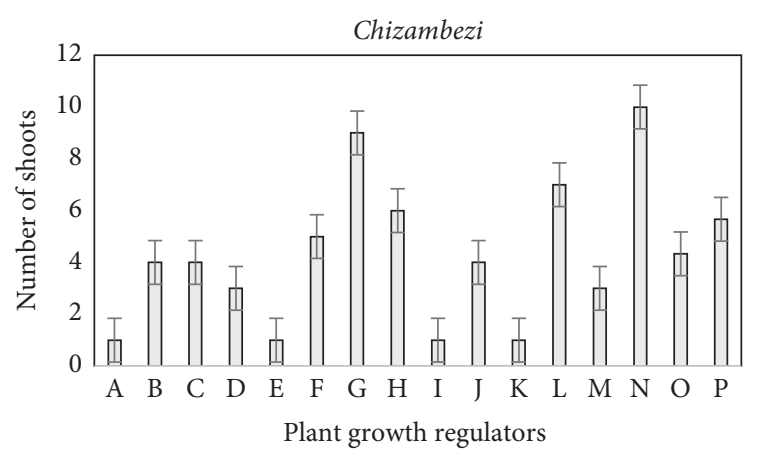

(b)

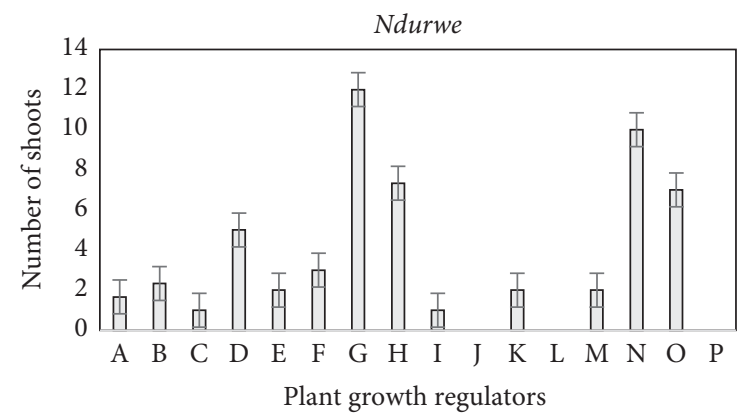

(d)

Figure 3: Mean shoot number of the Livingstone potato landraces in response to NAA: BAP in $\mathrm{mg} / \mathrm{l}$ application. $P<0.001$, LSD $=2.57$. Error bars represent standard errors of the differences. Plant growth regulators key: A $(0 \mathrm{mg} / \mathrm{l}: 0 \mathrm{mg} / \mathrm{l}), \mathrm{B}(0 \mathrm{mg} / \mathrm{l}: 0.5 \mathrm{mg} / \mathrm{l}), \mathrm{C}(0 \mathrm{mg} / \mathrm{l}: 1 \mathrm{mg} / \mathrm{l}), \mathrm{D}(0 \mathrm{mg} /$ l: $2 \mathrm{mg} / \mathrm{l}), \mathrm{E}(0.2 \mathrm{mg} / \mathrm{l}: 0 \mathrm{mg} / \mathrm{l}), \mathrm{F}(0.2 \mathrm{mg} / \mathrm{l}: 0.5 \mathrm{mg} / \mathrm{l}), \mathrm{H}(0.2 \mathrm{mg} / \mathrm{l}: 2 \mathrm{mg} / \mathrm{l}), \mathrm{I}(0.5 \mathrm{mg} / \mathrm{l}: 0 \mathrm{mg} / \mathrm{l}), \mathrm{J}(0.5 \mathrm{mg} / \mathrm{l}: 0.5 \mathrm{mg} / \mathrm{l}), \mathrm{J}(0.5 \mathrm{mg} / \mathrm{l}: 0.5 \mathrm{mg} / \mathrm{l}), \mathrm{K}$ $(0.5 \mathrm{mg} / \mathrm{l}: 1 \mathrm{mg} / \mathrm{l}), \mathrm{L}(0.5 \mathrm{mg} / \mathrm{l}: 2 \mathrm{mg} / \mathrm{l}), \mathrm{M}(1 \mathrm{mg} / \mathrm{l}: 0 \mathrm{mg} / \mathrm{l}), \mathrm{N}(1 \mathrm{mg} / \mathrm{l}: 0.5 \mathrm{mg} / \mathrm{l}), \mathrm{O}(1 \mathrm{mg} / \mathrm{l}: 1 \mathrm{mg} / \mathrm{l})$, and P $(1 \mathrm{mg} / \mathrm{l}: 2 \mathrm{mg} / \mathrm{l})$.

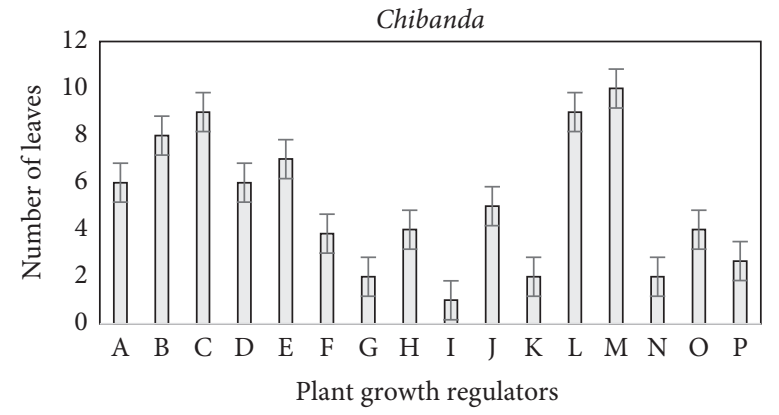

(a)

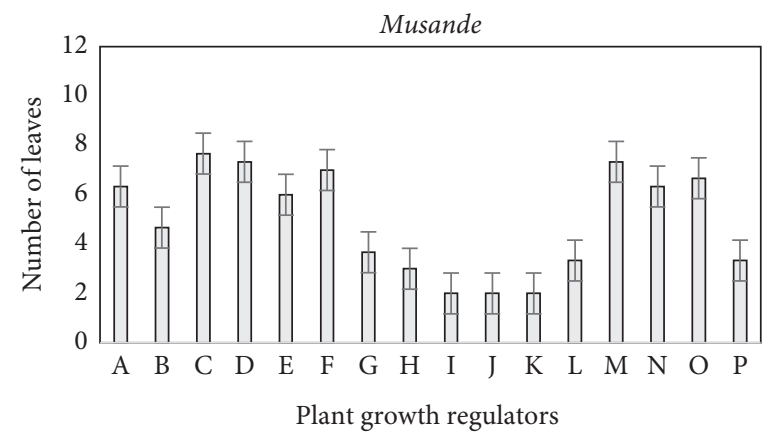

(c)

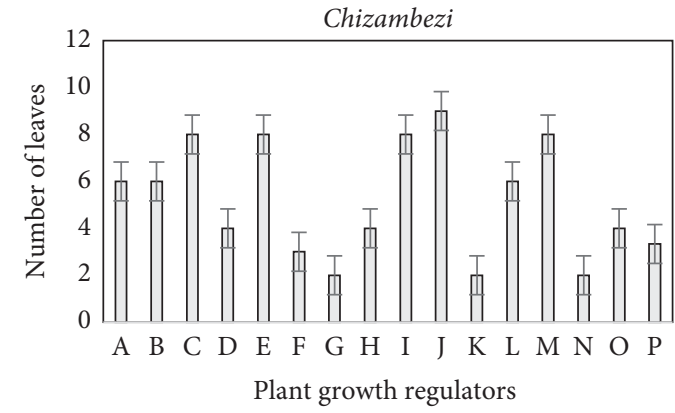

(b)

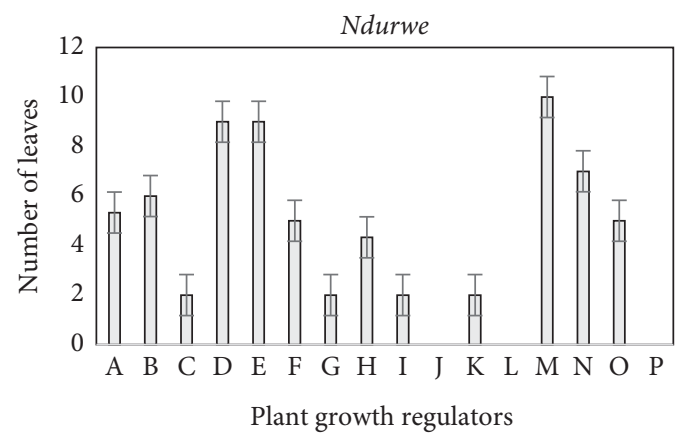

(d)

Figure 4: Mean leaf number of the livingstone potato landraces in response to NAA: BAP in $\mathrm{mg} / \mathrm{l}$ application. $P<0.001, \mathrm{LSD}=2.7$. Error bars represent standard errors of the differences. Key: A $(0 \mathrm{mg} / \mathrm{l}: 0 \mathrm{mg} / \mathrm{l}), \mathrm{B}(0 \mathrm{mg} / \mathrm{l}: 0.5 \mathrm{mg} / \mathrm{l}), \mathrm{C}(0 \mathrm{mg} / \mathrm{l}: 1 \mathrm{mg} / \mathrm{l}), \mathrm{D}(0 \mathrm{mg} / \mathrm{l}: 2 \mathrm{mg} / \mathrm{l}), \mathrm{E}$ $(0.2 \mathrm{mg} / \mathrm{l}: 0 \mathrm{mg} / \mathrm{l}), \mathrm{F}(0.2 \mathrm{mg} / \mathrm{l}: 0.5 \mathrm{mg} / \mathrm{l}), \mathrm{H}(0.2 \mathrm{mg} / \mathrm{l}: 2 \mathrm{mg} / \mathrm{l}), \mathrm{I}(0.5 \mathrm{mg} / \mathrm{l}: 0 \mathrm{mg} / \mathrm{l}), \mathrm{J}(0.5 \mathrm{mg} / \mathrm{l}: 0.5 \mathrm{mg} / \mathrm{l}), \mathrm{J}(0.5 \mathrm{mg} / \mathrm{l}: 0.5 \mathrm{mg} / \mathrm{l}), \mathrm{K}(0.5 \mathrm{mg} / \mathrm{l}:$ $1 \mathrm{mg} / \mathrm{l}), \mathrm{L}(0.5 \mathrm{mg} / \mathrm{l}: 2 \mathrm{mg} / \mathrm{l}), \mathrm{M}(1 \mathrm{mg} / \mathrm{l}: 0 \mathrm{mg} / \mathrm{l}), \mathrm{N}(1 \mathrm{mg} / \mathrm{l}: 0.5 \mathrm{mg} / \mathrm{l}), \mathrm{O}(1 \mathrm{mg} / \mathrm{l}: 1 \mathrm{mg} / \mathrm{l})$, and P (1 mg/l: $2 \mathrm{mg} / \mathrm{l})$. 


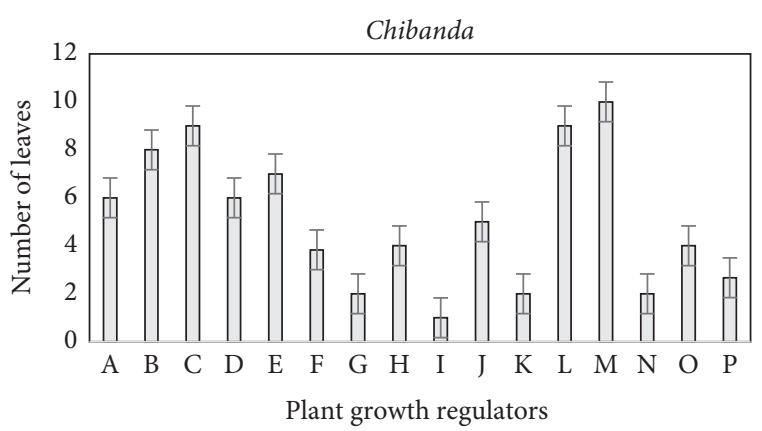

(a)

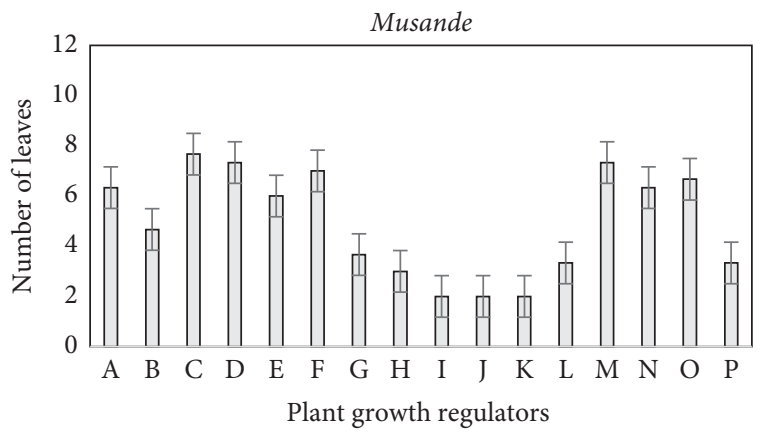

(c)

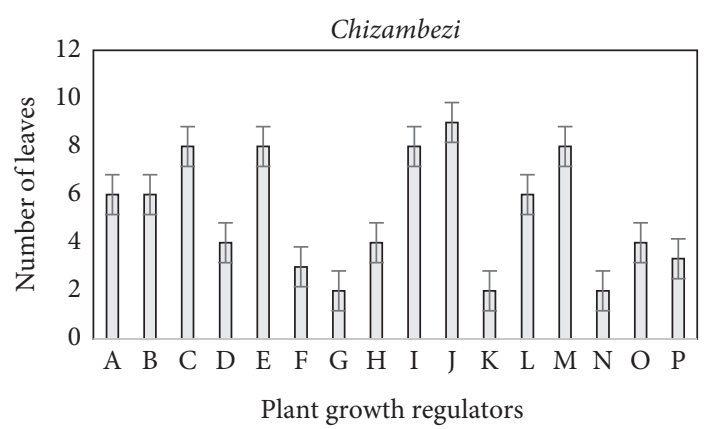

(b)

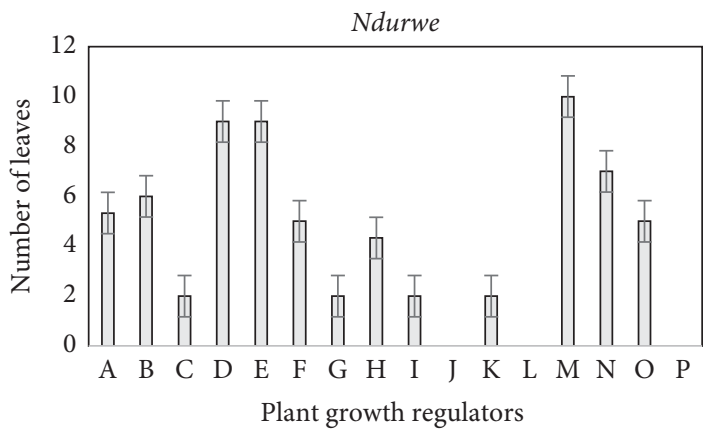

(d)

Figure 5: Mean node number of the Livingstone potato landraces in response to NAA: BAP in mg/l application. $P<0.001, \mathrm{LSD}=1.05$. Error bars represent standard errors of the differences. Plant growth regulators key: A $(0 \mathrm{mg} / \mathrm{l}: 0 \mathrm{mg} / \mathrm{l}), \mathrm{B}(0 \mathrm{mg} / \mathrm{l}: 0.5 \mathrm{mg} / \mathrm{l}), \mathrm{C}(0 \mathrm{mg} / \mathrm{l}: 1 \mathrm{mg} / \mathrm{l}), \mathrm{D}$ $(0 \mathrm{mg} / \mathrm{l}: 2 \mathrm{mg} / \mathrm{l}), \mathrm{E}(0.2 \mathrm{mg} / \mathrm{l}: 0 \mathrm{mg} / \mathrm{l}), \mathrm{F}(0.2 \mathrm{mg} / \mathrm{l}: 0.5 \mathrm{mg} / \mathrm{l}), \mathrm{H}(0.2 \mathrm{mg} / \mathrm{l}: 2 \mathrm{mg} / \mathrm{l}), \mathrm{I}(0.5 \mathrm{mg} / \mathrm{l}: 0 \mathrm{mg} / \mathrm{l}), \mathrm{J}(0.5 \mathrm{mg} / \mathrm{l}: 0.5 \mathrm{mg} / \mathrm{l}), \mathrm{J}(0.5 \mathrm{mg} / \mathrm{l}:$ $0.5 \mathrm{mg} / \mathrm{l}), \mathrm{K}(0.5 \mathrm{mg} / \mathrm{l}: 1 \mathrm{mg} / \mathrm{l}), \mathrm{L}(0.5 \mathrm{mg} / \mathrm{l}: 2 \mathrm{mg} / \mathrm{l}), \mathrm{M}(1 \mathrm{mg} / \mathrm{l}: 0 \mathrm{mg} / \mathrm{l}), \mathrm{N}(1 \mathrm{mg} / \mathrm{l}: 0.5 \mathrm{mg} / \mathrm{l}), \mathrm{O}(1 \mathrm{mg} / \mathrm{l}: 1 \mathrm{mg} / \mathrm{l})$, and $\mathrm{P}(1 \mathrm{mg} / \mathrm{l}: 2 \mathrm{mg} / \mathrm{l})$.

agreeing with findings by Kyesmu and Mantell [31]. Similar results were also obtained for sweet potato $[18,22]$ which is also a tuberous root like the Livingstone potato. Overall, the Musande landrace performed the best for all the growth parameters. The node which was the best explant was then used in the second experiment to determine the suitable PGR combination for the production of the plantlets.

Growth regulators used in tissue culture are synthetic chemical versions of natural plant growth regulators that are applied to plants to produce a desired effect such as shoot and root proliferation [32]. The most common plant growth regulators used in micropropagation include gibberellins, auxins, and cytokinins. Previous research has shown that the use of plant growth regulators is not necessary in the micropropagation of vegetatively propagated tuber crops [13]. However, other researchers have extensively demonstrated that there is merit in using these chemicals to enhance the growth and development of plants during micropropagation. In this study, naphthalene acetic acid (NAA) and benzyl amino purine (BAP) at different combinations were used for the micropropagation of the Livingstone potato so as to determine if the culture medium needed to be optimized for the local landraces in Zimbabwe.

4.1. Root and Shoot Initiation. Chizambezi and Chibanda initiated roots and shoots in the shortest time at high and low concentrations of NAA: BAP, while Musande took the longest time to initiate roots and shoots when NAA and BAP were absent from the MS culture medium. Liljana et al. [33] also achieved successful root and shoot initiation on potato with the addition of the same plant growth regulators added to the MS culture medium. A similar result was also reported by Ezeibekwe et al. [34], on their work on white yams (Dioscoera rotundata L.). According to Schmülling [35], the ratio of cytokinins to auxins in vitro determines the differentiation of cultured plant tissues to either shoots or roots. In this study, a combination of NAA and BAP produced the best results for shoot initiation for Chizambezi and Chibanda compared to the use of BAP acting alone in the MS medium culture. $\mathrm{BAP}$ is regarded as the best phytohormone for shoot initiation [36, 37]. This result is supported by findings by Kabir [38], on the research on cassava. Chizambezi and Chibanda both benefitted from the addition of the plant growth regulators even in low quantities, thus disproving the findings of Allemann [13], who worked on the same Plectranthus species. Genetic differences also accounted for the difference in performance amongst the four landraces.

4.2. Shoot, Leaf, and Node Number of the Plantlets. The highest shoot number was recorded in treatments that had a combination of NAA: BAP at $0.2 \mathrm{mg} / 1: 1 \mathrm{mg} / \mathrm{l}$ for Musande and Ndurwe. However, the shoots were structurally small and short. Masekesa et al. [39] showed that high BAP 


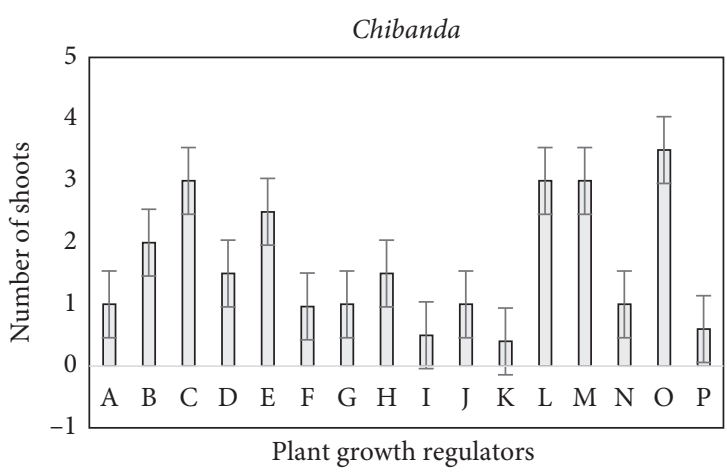

(a)

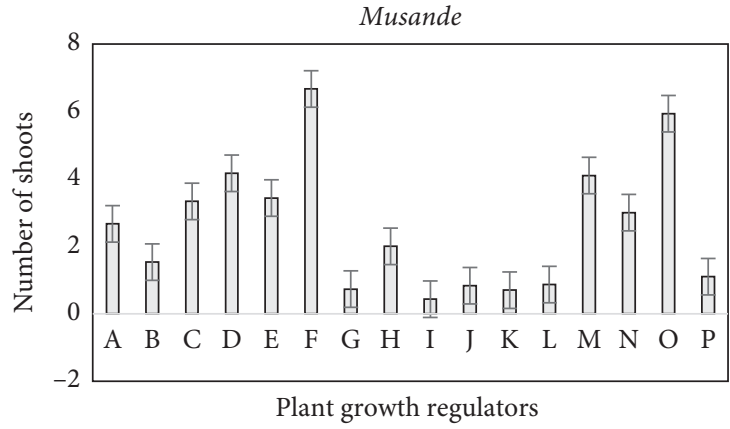

(c)

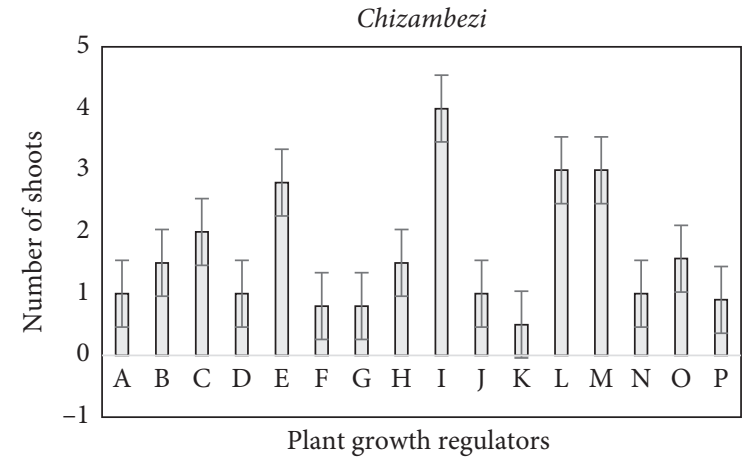

(b)

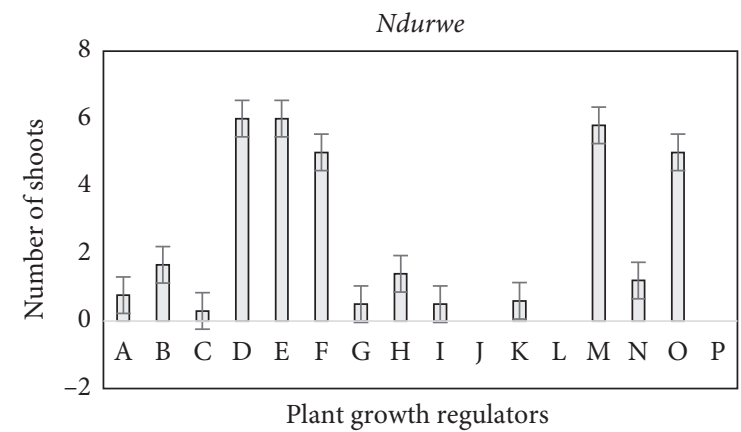

(d)

Figure 6: Mean shoot length of the livingstone potato landraces in response to NAA: BAP in mg/l application. $P<0.001, \mathrm{LSD}=1.53$. Error bars represent standard errors of the differences. Plant growth regulators key: A $(0 \mathrm{mg} / \mathrm{l}: 0 \mathrm{mg} / \mathrm{l}), \mathrm{B}(0 \mathrm{mg} / \mathrm{l}: 0.5 \mathrm{mg} / \mathrm{l}), \mathrm{C}(0 \mathrm{mg} / \mathrm{l}: 1 \mathrm{mg} / \mathrm{l}), \mathrm{D}$ $(0 \mathrm{mg} / \mathrm{l}: 2 \mathrm{mg} / \mathrm{l}), \mathrm{E}(0.2 \mathrm{mg} / \mathrm{l}: 0 \mathrm{mg} / \mathrm{l}), \mathrm{F}(0.2 \mathrm{mg} / \mathrm{l}: 0.5 \mathrm{mg} / \mathrm{l}), \mathrm{H}(0.2 \mathrm{mg} / \mathrm{l}: 2 \mathrm{mg} / \mathrm{l}), \mathrm{I}(0.5 \mathrm{mg} / \mathrm{l}: 0 \mathrm{mg} / \mathrm{l}), \mathrm{J}(0.5 \mathrm{mg} / \mathrm{l}: 0.5 \mathrm{mg} / \mathrm{l}), \mathrm{J}(0.5 \mathrm{mg} / \mathrm{l}:$ $0.5 \mathrm{mg} / \mathrm{l}), \mathrm{K}(0.5 \mathrm{mg} / \mathrm{l}: 1 \mathrm{mg} / \mathrm{l}), \mathrm{L}(0.5 \mathrm{mg} / \mathrm{l}: 2 \mathrm{mg} / \mathrm{l}), \mathrm{M}(1 \mathrm{mg} / \mathrm{l}: 0 \mathrm{mg} / \mathrm{l}), \mathrm{N}(1 \mathrm{mg} / \mathrm{l}: 0.5 \mathrm{mg} / \mathrm{l}), \mathrm{O}(1 \mathrm{mg} / \mathrm{l}: 1 \mathrm{mg} / \mathrm{l}), \mathrm{and} \mathrm{P}(1 \mathrm{mg} / \mathrm{l}: 2 \mathrm{mg} / \mathrm{l})$.

TABLE 4: Summary of landrace performance due to application of PGRs.

\begin{tabular}{|c|c|c|c|}
\hline Parameter & \multicolumn{3}{|c|}{ Landrace and NAA: BAP combination (mg/l) } \\
\hline $\begin{array}{l}\text { Days to root } \\
\text { initiation }\end{array}$ & \multicolumn{3}{|c|}{ Chibanda and Chizambezi $\mathrm{K}(0.5 \mathrm{mg} / \mathrm{l}: 1 \mathrm{mg} / \mathrm{l})$} \\
\hline $\begin{array}{l}\text { Days to shoot } \\
\text { initiation }\end{array}$ & \multirow{2}{*}{\multicolumn{3}{|c|}{$\begin{array}{l}\text { Chibanda and Chizambezi D }(0 \mathrm{mg} / \mathrm{l}: 2 \mathrm{mg} / \mathrm{l}, \mathrm{H}(0.2 \mathrm{mg} / \mathrm{l}: 2 \mathrm{mg} / \mathrm{l}) \text { and } \\
\mathrm{L}(0.5 \mathrm{mg} / \mathrm{l}: 2 \mathrm{mg} / \mathrm{l} \\
\text { Ndurwe and Musande } \mathrm{G}(0.2 \mathrm{mg} / \mathrm{l}: 1 \mathrm{mg} / \mathrm{l}) \text { shoots were structurally small and short }\end{array}$}} \\
\hline No. of shoots & & & \\
\hline No. of leaves & \multirow{2}{*}{\multicolumn{2}{|c|}{$\begin{array}{cc}\text { Chibanda, Chizambezi, and Ndurwe } & \text { Chizambezi I-J }(0.5 \mathrm{mg} / \mathrm{l}: \\
\text { B-E }(0 \mathrm{mg} / \mathrm{l}: 0.5 \mathrm{mg} / \mathrm{l}-0.2 \mathrm{mg} / \mathrm{l}: 0 \mathrm{mg} / & 0 \mathrm{mg} / \mathrm{l}-0.5 \mathrm{mg} / \mathrm{l}: 0.5 \mathrm{mg} / \mathrm{l}) \\
\text { l) } & \text { Chizambezi } \mathrm{I}(0.5 \mathrm{mg} / \mathrm{l}: \\
\text { Chibanda and Ndurwe A-E 0 mg/l: } & 0 \mathrm{mg} / \mathrm{l})\end{array}$}} & $\begin{array}{l}\text { Ndurwe, Chizambezi, and Chibanda L-M } \\
\quad(0.5 \mathrm{mg} / \mathrm{l}: 2 \mathrm{mg} / \mathrm{l}-1 \mathrm{mg} / \mathrm{l}: 0 \mathrm{mg} / \mathrm{l})\end{array}$ \\
\hline No. of nodes & & & $\begin{array}{l}\text { Chizambezi, Ndurwe, and } \\
\text { Musande M (1 mg/l:0 mg/l) }\end{array}$ \\
\hline $\begin{array}{l}\text { Length of } \\
\text { shoots }\end{array}$ & $\begin{array}{l}\text { Musande and Ndurwe D-F (0 mg/l: } \\
2 \mathrm{mg} / \mathrm{l}-0.2 \mathrm{mg} / \mathrm{l}: 0.5 \mathrm{mg} / \mathrm{l})\end{array}$ & Ndurwe M (1 mg/l: $0 \mathrm{mg} / \mathrm{l})$ & Musande O (1 mg/l: $1 \mathrm{mg} / \mathrm{l})$ \\
\hline
\end{tabular}

concentrations tend to produce shoots that are shorter in stature because cytokinins encourage growth mainly through promoting cell division at the expense of cell expansion. With regards to the leaf number, high numbers per main shoot were observed for Chizambezi, Chibanda, and Ndurwe under NAA alone, BAP alone, and when the two plant growth regulators were combined at varying concentrations. The variation in mean leaf numbers amongst the three landraces could be linked to the levels of endogenous cytokinins available in the buds of the explant instead of the influence of the ones added externally as reported by
Demeke et al. [40]. Musande had the lowest leaf number, a result which could be attributed to the fact that leaf number is a function of genotype specificity [41].

The number of nodes is an important aspect in the micropropagation, especially in this study where the node was the explant of choice. The higher the number of nodes produced, the faster the production of more plantlets will be carried out through subculturing. All four landraces responded well to the application of the PGRs at varying concentrations $(0: 0-1: 1) \mathrm{mg} / \mathrm{l}$ by producing high node numbers on the shoots. This result is in line with findings by 
[34] on white yams although at a concentration of NAA: BAP $(0.5: 0.2) \mathrm{mg} / \mathrm{l}$.

4.3. Shoot Length of the Plantlets. Musande and Ndurwe produced the longest shoots compared to the other two landraces when cultured using the NAA: BAP at a concentration of range of $0-1 \mathrm{mg} / \mathrm{l}: 0-0.5 \mathrm{mg} / \mathrm{l}$, respectively. This can be attributed to the synergistic effect of the NAA and the BAP when applied together at a low concentration [42]. This result is also supported by Demeke et al. [40] who achieved a similar result on nodal explants of cassava (Manihot esculenta). On the other hand, Ezeibekwe et al. [34] found contrasting results with the white yam where longer shoots were obtained without the addition of NAA and BAP to the MS culture medium. The influence of the genotype could also have impacted the results obtained amongst the landraces and their response to the PGRs.

\section{Conclusions}

The obtained results showed that the best explant type were nodes where the Musande landrace had the best results for this explant type. While all four landraces were able to produce plantlets from the nodes, Chizambezi was the best landrace with regards to the growth parameters measured under the different NAA: BAP concentrations. Chizambezi is highly recommended for the rapid multiplication of Livingstone potato using tissue culture. Results from this study also clearly demonstrated that the addition of PGRs is essential for optimizing the growth media in enhancing the micropropagation of Livingstone potato. Commercial production of plantlets can, therefore, be carried out in Zimbabwe using the optimized protocol to provide healthy planting material for the communal farmers for improved productivity. In addition, production of planting material using tissue culture ensures the preservation of the germplasm, a critical aspect considering that the crop is underutilised and is facing extinction in Zimbabwe.

\section{Data Availability}

The data used to support the findings of this study are available from the corresponding author upon request.

\section{Conflicts of Interest}

The authors declare that they have no conflicts of interest.

\section{Acknowledgments}

The authors would like to acknowledge the International Foundation for Science (IFS grant no: C/5431-1), the Deutscher Akademischer Austausch Dienst (DAAD: A/ 1395622) in country scholarship, and the RU/2018/Post Doc/11 Post-Doctoral research grant for funding the research.

\section{References}

[1] R. R. Schippers, African Indigenous Vegetables: An Overview of the Cultivated Species, University of Greenwich, Natural Resources Institute, London, UK, 2000.

[2] P. D. Dhliwayo, "Underexploited tuber crops in Zimbabwe: a study on the production of livingstone potato (Plectranthus exculentus)," Plant Genetic Resource Newsletter, vol. 130, pp. 77-80, 2002.

[3] G. Kujeke, R. Masekesa, D. Icishahayo, E. Ngadze, and U. Mazarura, "A survey of the production practices of livingstone potato (Plectranthus esculentus), an indigenous and underutilized vegetable in Zimbabwe," Journal of Agriculture and Ecology Research International, vol. 4, no. 4, pp. 175-187, 2015.

[4] M. Otroshy and P. C. Struik, "Effect of size of normal seed tubers and growth regulator application on dormancy, sprout behaviors, growth vigour and quality of normal seed tubers of different potato cultivar," Research Journal of Seed Science, vol. 1, no. 1, pp. 41-50, 2008.

[5] I. Safwan and U. Mohammed, "Review on the nutritional value, cultivation and utilization potential of some minor and under-utilized indigenous root and tuber crops in Nigeria," International Journal of Advanced Research, vol. 4, no. 3, pp. 1298-1303, 2016.

[6] H. D. Tindall, Vegetables in the Tropics, Macmillan Press Limited, London, UK, 1983.

[7] N. Haq, "Women reintroducing neglected crops," LEISA Magazine, vol. 20, no. 1, pp. 28-29, 2004.

[8] B. Woodward, J. Brink, and D. Berger, "Can agricultural biotechnology make a difference in Africa?" The Journal of Agrobiotechnology Management and Economics, vol. 2, no. 34, 2000.

[9] E. Venkatasalam, R. Sood, K. K. Pandey, V. Thakur, A. K. Sharma, and B. P. Singh, "Development of low cost technology for in vitro mass multiplication of potato (Solanum tuberosum L.)," African Journal of Agricultural Research, vol. 8, no. 49, pp. 6375-6382, 2013.

[10] E. F. George, M. A. Hall, and G.-J. D. Klerk, "Plant growth regulators II: cytokinins, their analogues and antagonists," Plant Propagation by Tissue Culture, vol. 1, pp. 205-226, 2008.

[11] P. M. Kyesmu, "Plectranthus esculentus N.E.Br. A minor tuber crop in dire need of rescue from extinction," Lamiales Newsletter, no. 3, pp. 3-5, 1994.

[12] P. M. Kyesmu, Development of "in vitro" propagation and genetic fingerprinting techniques for the West African tuber crop "rizga" (Plecrtanthus esculentus' N.E.Br. Syn'coleus dazo'A. Chev), Ph.D. thesis, Imperial College London (University of London), London, UK, 1996.

[13] J. Allemann, Evaluation of Plectranthus esculentus N.E.Br as a potential vegetable crop, Ph.D. thesis, University of Pretoria, Pretoria, South Africa, 2002.

[14] K. F. Hannweg, Induced Polyploidy as a Tool for the Development of Novel South African Indigenous Crops, University of KwaZulu-Natal, Durban, South Africa, 2015.

[15] V. Lebot, Tropical Root and Tuber Crops: Cassava, Sweet Potato, Yams and Aroids, CABI Centre for Agriculture and Bioscience International, Wallingford, UK, 2009.

[16] T. Murashige and F. Skoog, "A revised medium for rapid growth and bio assays with tobacco tissue cultures," Physiologia Plantarum, vol. 15, no. 3, pp. 473-497, 1962.

[17] X. Shen, W. S. Castle, and F. G. Gmitter, "In vitro shoot proliferation and root induction of shoot tip explants from 
mature male plants of Casuarina cunninghamiana miq." Hortscience, vol. 45, no. 5, pp. 797-800, 2010.

[18] F. Addae-Frimpomaah, J. Amponsah, and T. K. Tengey, "Regeneration of three sweet potato (Ipomoea batatas (L.)) accessions in Ghana via, meristem and nodal culture," International Journal of Plant Breeding and Genetics, vol. 8, no. 3, pp. 121-138, 2014.

[19] S. J. Butt, S. Varis, I. A. Nasir, S. Sheraz, A. Shahid, and Q. Ali, "Micro propagation in advanced vegetable production: a review," Advancements in Life Sciences, vol. 2, no. 2, pp. 48-57, 2015.

[20] P. Chivenge, T. Mabhaudhi, A. Modi, and P. Mafongoya, "The potential role of neglected and underutilised crop species as future crops under water scarce conditions in sub-saharan Africa," International Journal of Environmental Research and Public Health, vol. 12, no. 6, pp. 5685-5711, 2015.

[21] C.-Y. Ko, J.-P. Kung, and R. M. Donald, "In vitro micropropagation of white dasheen (Colocassia esculenta)," African Journal of Biotechnology, vol. 7, no. 1, pp. 41-43, 2008.

[22] R. Doliński and A. Olek, "Micropropagation of sweet potato (Ipomoea batatas (L.) Lam.) from node explants," Acta Scientiarum Polonorum, Hortorum Cultus, vol. 12, no. 4, pp. 117-127, 2013.

[23] A. Ngetich, S. Runo, O. Ombori et al., "Low cost micropropagation of local varieties of taro," British Biotechnology Journal, vol. 6, no. 4, pp. 136-145, 2015.

[24] A. S. Abubakar, S. U. Yahaya, A. S. Shaibu et al., "In vitro propagation of sweet potato (Ipomoea batatas (L.) Lam.) cultivars," Agricultural Science Digest, vol. 38, no. 1, pp. 17-21, 2018.

[25] B. Mengs, M. C. Chimdessa, and E. Abraha, "In vitro propagation of sweet potato (Ipomoea batatas (L.) Lam.) through lateral bud culture," International Journal of Innovative Pharmaceutical Sciences and Research, vol. 6, no. 7, pp. 1-12, 2018.

[26] K. Hannweg, W. Steyn, and I. Bertling, "In vitro-induced tetraploids of Plectranthus esculentus are nematode-tolerant and have enhanced nutritional value," Euphytica, vol. 207, no. 2, pp. 343-351, 2016.

[27] F. Asghari, B. Hossieni, A. Hassani, and H. Shirzad, "Effect of explants source and different hormonal combinations on direct regeneration of basil plants (Ocimum basilicum L.)," Australian Journal of Agricultural Engineering, vol. 3, no. 1, pp. 12-17, 2012.

[28] R. H. Smith, Plant Tissue Culture: Techniques and Experiments, Academic Press, Cambridge, MA, USA, 2013.

[29] D. Fadel, "Effect of different strength of medium on organogenesis, phenolic accumulation and antioxidant activity of spearmint (Mentha spicata L.)," The Open Horticulture Journal, vol. 3, no. 1, pp. 31-35, 2010.

[30] K. O. Ogero, "Low cost tissue culture technology in the regeneration of sweet potato (Ipomoea batatas (L) Lam)," Research Journal of Biology, vol. 2, no. 2, pp. 51-58, 2012.

[31] P. M. Kyesmu and S. H. Mantell, "Callus initiation and regeneration in a minor tuber crop "rizga" (Plectranthus esculentus N.Br.)," Global Journal of Agricultural Sciences, vol. 1, no. 1, pp. 55-62, 2002.

[32] K. Upreti and M. Sharma, "Role of plant growth regulators in abiotic stress tolerance," in Abiotic Stress Physiology of Horticultural Crops, pp. 19-46, Springer, Berlin, Germany, 2016.

[33] K. G. Liljana, S. Mitrev, T. Fidanka, and I. Mite, "Micropropagation of potato Solanum tuberosum L," Electronic Journal of Biology, vol. 8, no. 3, pp. 45-49, 2012.
[34] I. O. Ezeibekwe, C. L. Ezenwaka, F. M. Mbagwu, and C. I. N. Unamba, "Effects of combination of different levels of auxin (NAA) and cytokinin (BAP) on in vitro propagation of Dioscorea rotundata L. (white yam)," Journal of Molecular Genetics, vol. 1, no. 2, pp. 18-22, 2009.

[35] T. Schmülling, Cytokinin. Encyclopedia of Biological Chemistry, Academic Press, Cambridge, MA, USA, 2004.

[36] R. N. Trigiano and D. J. C. Gray, Plant Tissue Culture: Concepts and Laboratory Exercises, CRC Press, Boca Raton, FL, USA, 2000.

[37] N. I. C. Onwubiku and C. I. Onuoch, "Micropropagation of cassava (Manihot esculantum crantz) using different concentrations of benzyaminiopurine (BAP)," Journal of Engineering and Applied Sciences, vol. 2, no. 7, pp. 1229-1231, 2007.

[38] M. Kabir, "In vitro propagation of cassava (Manihot esculenta Crantz)," Nuclear Science and Applications, vol. 24, no. 1-2, pp. 23-28, 2015.

[39] R. T. Masekesa, E. Gasura, A. Matikiti et al., "Effect of BAP, $\mathrm{NAA}$ and $\mathrm{GA}_{3}$, either alone or in combination, on meristem culture and plantlet establishment in sweet potato (cv brondal)," African Journal of Food, Agriculture, Nutrition and Development, vol. 16, no. 1, pp. 10649-10665, 2016.

[40] Y. Demeke, W. Tefera, N. Dechassa, and B. Abebie, "Effects of plant growth regulators on in vitro cultured nodal explants of cassava (Manihot esculenta crantz) clones," African Journal of Biotechnology, vol. 13, no. 28, pp. 2830-2839, 2014.

[41] S. P. Meher, "Effect of planting time and growth regulator treatments on flowering and yield of chrysanthemum (Chrysanthemum morifolium ramat)," Crop Research-Hisar, vol. 18, no. 3, pp. 345-348, 1999.

[42] S. H. Howell, S. Lall, and P. Che, "Cytokinins and shoot development," Trends in Plant Science, vol. 8, no. 9, pp. 453-459, 2003. 